\title{
DIGITAL REPRESENTATION TECHNIQUES FOR OLFACTORY FEATURES
}

\author{
Dewanand A. Meshram ${ }^{1}$, Dipti D. Patil ${ }^{2}$ \\ ${ }^{1}$ STES, RMD Sinhgad School of Engineering, Warje, Savitribai Phule Pune University, Pune, India \\ ${ }^{2}$ MKSSS's Cummins College of Engineering for women, Pune, India \\ ${ }^{1}$ meshramda@gmail.com.2iotivt@gmail.com
}

\begin{abstract}
Digital representation of odor has a basic principal of chemosensory organism of sensory molecules. A body organism responds to external odor environments. A body of animal/human perceives the odor in the form of molecule structure. But the questions still arises how that odor molecule is presented in the digital format. Also how it act a specific odor behavior. The mechanism used in animal/human body is to solve the problem as per thought process level. Thought process retrieve the stored molecule of odor in a visual smell. Similar concepts are carrying forward to store in a computer system with the help of electron. The system is applied to perform Machine-learned odor recognition from physico-chemical properties of volatile molecules. The properties of volatile molecules are to match the pattern of chemosensory organisms. Artificial intelligence is used to predict the molecule of smell by applying neural network. This paper focuses on the behavior of odors and its digital representation techniques for olfactory features.
\end{abstract}

Index Terms - chemosensory organism molecule, cilia, GNN, KNN, MOX, Neuron, Odor, Olfactory bulb, PCA, SVM

\section{INTRODUCTION}

$\mathrm{S}_{\mathrm{H}}^{\mathrm{N}}$ MELL is a remembrance of past things in a suggestive ENSE. Most of the animal smell is an ancient sense, however human think a smell as a visual sense, they rely identify the food, explosive material, industry, medical, etc., number of organisms of human/animal body behave in the response to smell by most efficient communicating and interpreting their surroundings[1]. In the response of behavior smell is essential to the organism's survival to get the result from non-conscious perception of odors. A body organism responds to an external odor environment. It has ability to perceive in past, present, future in a simple celled organism, protista and bacteria, such as mammals, arthropods and mollusks in complex metazoans. The large amount of information provides by chemoreception sensory organisms. It is often very specific about the food, danger and other specified territory areas [2].

Perception of odors has unique scent, generally determined by olfactory identity, amazing ability to distinguish a mixture of odors. Animals/humans have ability to be familiar with more or less 10,000 scents ranging from pleasurable to un-pleasurable scents of past, present and future. Even though, many domestic and wild animals have greater sensitivity of odors than human. Human consciously

detect wide spectrum of odor varies from emotional and cognitive responses. But question arises in a mind that, do human recognize other sense of odor without concentration awareness of this perception organisms and behave as per the smell? How do chemosensory organisms react in a body for specific odors lead to exact thoughts, stored memory, and act all behaviors? Answer of these questions is yes when the smell is prehistoric or visual to the sensory organisms' species. The mechanism of sensory organisms developed to recognize various odors and communicate past, present, future olfactory information to the brain from the nose. The information is decoded to thought level process, to provide internal representation of the real world [1,2, and 3].

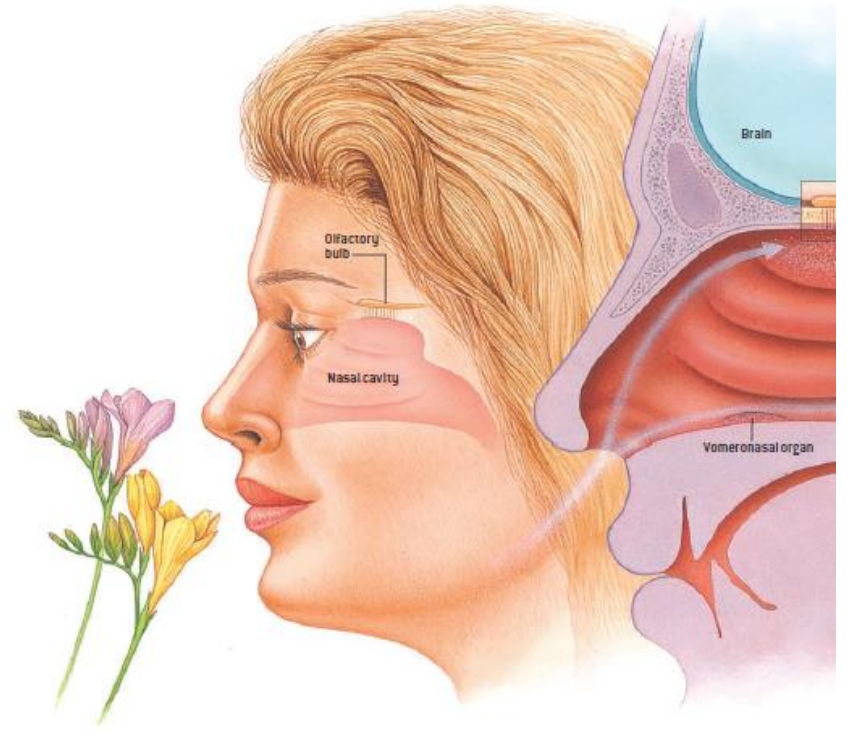

Fig. 1 scent behavior from nose to brain [1].

Most of the researchers have identified the human apparatus to identify the distinct steps that characterized olfaction future in the way of human smell [9]. The essential framework of human nose, brain and olfactory organism has been understood. It begins with inhale, air sample compound that contains molecules of odors that moves at the place of posterior of the nose known as olfactory epithelium present between the nasal cavity and olfactory bulb. The air sample 
compound transmit the mixture of volatile compounds through the mucus coating of olfactory epithelium, where sensory communication split ends of the nerve cells beginning one end of each neuron, hair-like sensors called cilia comes direct contact with air sample compound molecules. The sensory cells are enclosed with numerous cilia hair structure by means of sensory receptor located on the outer membranes $[6,10]$. Approximately every 30days, olfactory cells are replicated in a specialized neurons.

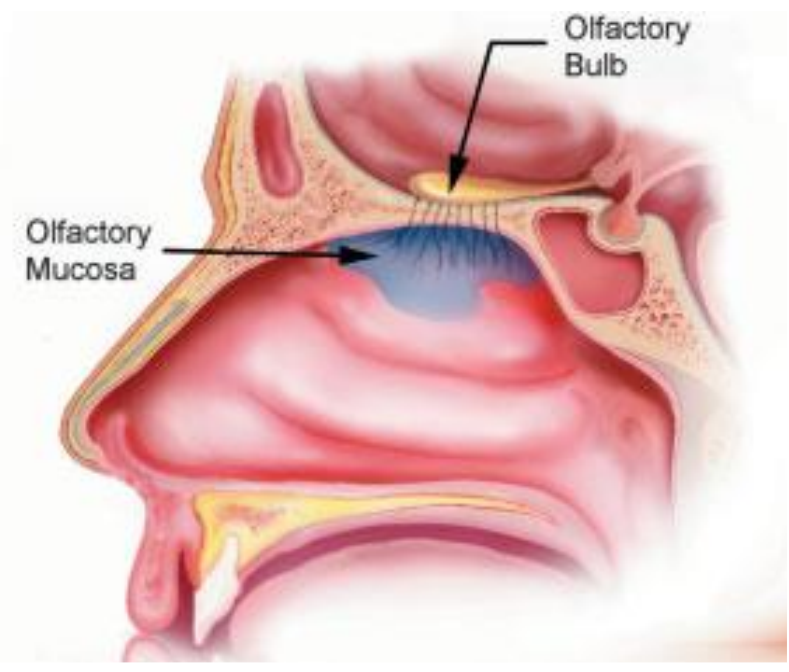

Fig 2: Olfactory mucosa and Olfactory bulb.

Olfactory mucosa is located in a small region of nasal cavities. In the nasal cavities there are number of receptors for sense of smell. The number of thin lines indicated in figure 2 shows the bipolar neurons which are pass the information from olfactory mucosa to the olfactory bulb. The odor interacts with nasal cavity, olfactory mucosa and olfactory bulb and ultimately passes it to the brain. The odor intensity is remarkably high and low sensitivity odor recognition from physico-chemical properties of volatile molecules. The molecule compounds can be detected by human at concentration in the low parts-per-billion/trillion (ppt/ppb) [8]. Olfactory receptor signals terminate in the olfactory bulb, where the dendrites of olfactory neurons form a small clusters called plural for glomerulus. It consists of several thousands of neurons receptors come together on the dendrites of tiny collection of olfactory bulb neurons. These include granule cells, mitral cells, tufted relay neurons and periglomerular neurons. The combination of mitral cells and tufted relay neurons form connection with olfactory mucosa in the glomeruli. In the importance of odor, new neurons added to the olfactory bulb to match the physicchemical properties of volatile molecules.

The digital transformation of an odor are discussed with special focus on primary thoughts of smell will follow the next section. Section III; describe the key terminology used in odors.

How that molecule is difficult to represent in digital format by using molecule structure and inhale capability of odor discussed in Section IV. Section V is used how that receptor code of odor used with different types of sensors and algorithms were discussed. Section VII contains the number of classifier and sensors used by different scholars. The last section brings the conclusion remarks of the paper.

\section{PRIMARY THOUGHTS OF SMELL}

Olfaction is a smell of sense and smell is a sense shared by human living organisms. It is an incredible range to play a critical to analyze and re-act the real world. For human being have ability to enjoy because of sense of smell and test, latter they can also trigger good memories. In our everyday lives odor allows us to appreciate all the fragrances like rose or favorite perfume. However aroma has not received the intensity of identical level of concentration from machine learning researchers. Fig 3 describes the state of the art and motivation of olfaction system. Artificial Intelligence system is having a capability to work like human nose because of odor perception olfaction. It has 400 dissimilar types of olfactory receptors; articulated in 1 million olfactory sensory neurons in a tiny bit of tissue called olfactory bulb \& then further structures in the brain.

The motivation the thought is to predict odor molecules by training an Artificial Intelligence system. The researchers are developing a neural network to identify artificial vanilla flavor by odor molecule pattern recognition system.

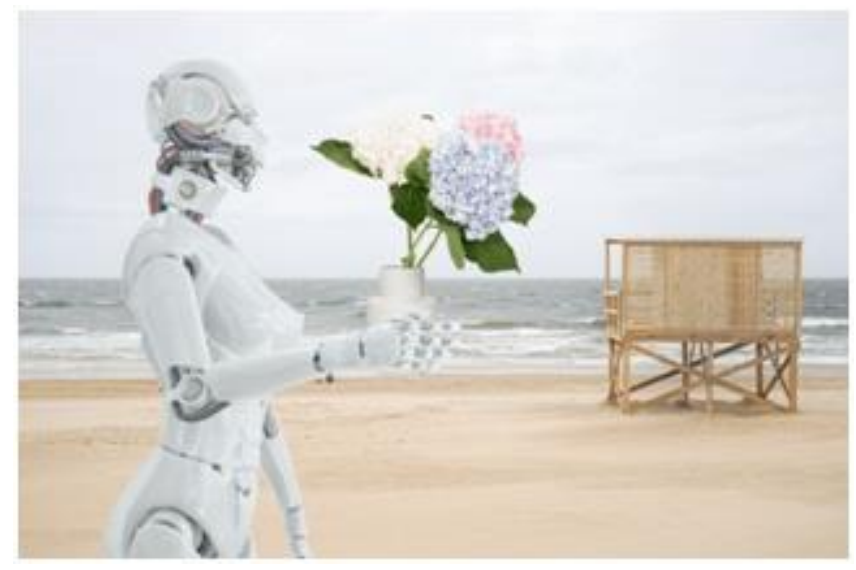

Fig 3: training an ai to predict a molecules-smell [15]

Tiny odorant molecules are the fundamental building blocks of flavor and fragrance. Each molecule preserves numerous odor descriptors. For example, vanillin has descriptors such as sweet, vanilla, creamy and chocolate as a result of odor predication is also a multi accountable classification problem. Molecules structure is represent in the form of graphs as shown in fig 4. Therefore the graph neural network (GNN) is a category of deep neural network 
intended to operate on graph as input to honestly predict the odor descriptor for creature molecules. The number of molecules is interconnected to each other with boding proteins.

Fig. 4 represents the graph neural network for odor prediction. Every atom have molecule to represent a graph. Atoms form the vertices along with bonds form the edges. GNN are the accepted model of preference for their understanding. The question is arises how does one molecule structure is translate in to a graph illustration.

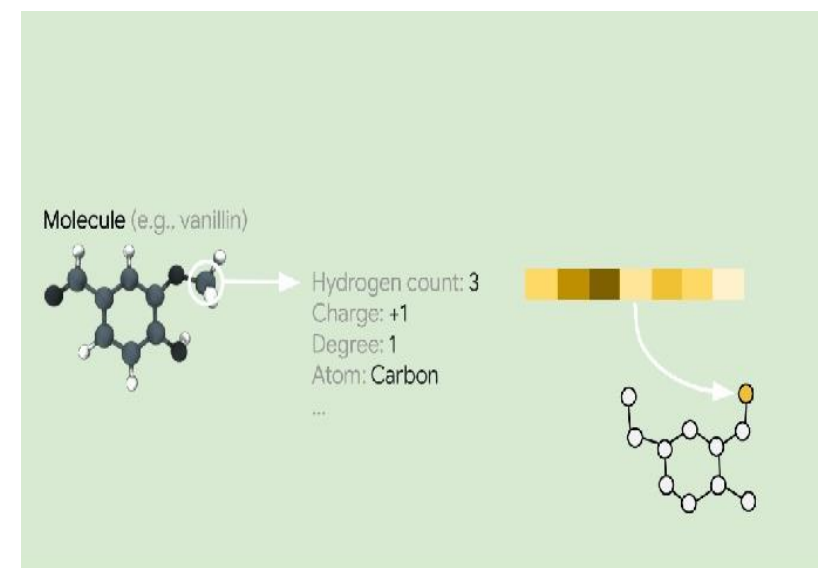

Fig 4: node representation as a vector [16]

Primarily, each node in the graph is represent as a vector by means of any preferred feature i.e. atom identity, atom charge, etc. Atom identity is unique identification atom and atom charge is an exchange of photon and neutrons. In the graph a series of message passing to its neighbors by broadcasting its current value of each node. Every node is going to update by revise function then takes the assortment of vectors sent to it. This procedure preserve frequently until finally all the nodes in the graph are summarize on its own vector. Those single vectors represent the entire molecule can the passed in to a fully associated network as learned molecular featurization. The complete process is shown in fig. 5.

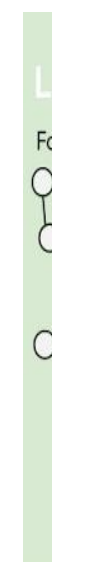

Fig. 5: Adjacent node and layers (NN) [16]

Fig. 6 illustrate the GNN of odor predication. Translate the vanillin structure of molecule in to generate graph neural network layers. The $\mathrm{N}$ numbers of layer discover an enhanced illustration of the nodes. These nodes are concentrated in to a single vector and voted for in to neural network that is used toward visualize compound odor descriptors. The NN can predict a molecule descriptor like creamy, sweet, chocolate, then the NN network decided that the molecule represent is vanillin shown in fig. 6 to describe the complete process of identification of odor molecule.

The above figure 1, 2,3,4,5 and 6 describes the idea of odors and how it is stored in a computer system in the digital form. It is an idea to describe the representation of pleasant and unpleasant odor from real world form to digital form.

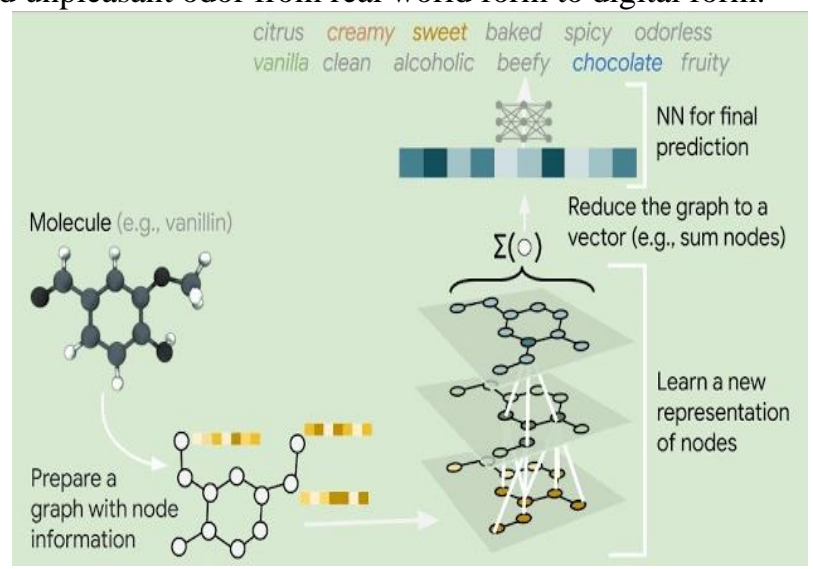

Fig. 6: GNN of odor prediction [16] 


\section{KEY TERMINOLOGY USED IN ODORS}

In olfaction when we have to identify the specified odor, we should match the pattern of odor which is stored in brain. The following key terminology is used for better understanding.

A. Atomic mass: "Atomic mass expressed in a unit of atomic mass in the pattern of mass particles from organic compound" [9].

B. Odor: "When the odorant (gas) compound molecules interact with receptors on cilia on the olfactory neurons in the human nose, the thought process is generated at that sensation event" [9].

C. Odor detection threshold: "Odorant gas may be detected by a subject at the minimal concentration level” [9].

D. Odor recognition threshold: "The odorant gas correctly identified by a subject at the minimum concentration level", [9].

E. Odor unit: "The odor concentration is detected at the specific threshold defined by European standards Technical Committee" [9]. It is measured in ppm (parts-per-millions), ppb (parts-per-billions)

F. Olfaction: "The sense of smell".

G. Olfactory neurons: "The olfactory neurons reside in a thin layer on the roof of the nasal cavity called as olfactory epithelium" [9]. It is a nerve cell sensitive to odors.

H. Receptor: "Specific compounds can bind with a molecular structure in the surface of a nerve cell, also a sensory nerve terminal that responds to stimuli" [9].

\section{WHAT WILL HAPPEN WHEN WE INHALE}

Olfactory epithelium is a small region of a nose. It use to take initiate a detection of odors. The chemical molecule dissolved act together with special receptors called odorant requisite proteins. The requisite proteins of the molecule, receptors instigate an electrical signal that transmit to brain center designed for processing of the olfactory information via olfactory bulb. Many researchers advise that odor favoritism involve a huge number of distinct olfactory receptors. Scientist believe that various sensory receptors act to the discrete part of an odors structure because of several chemical group of each characteristics of receptors. To make a distinction in the different smell, brain have got to determine the particular mixture of sensory receptors that are activate by a specific odor.

Remembering of the chemosensory molecule has major factor of odor molecular shape and size. Sensory organism have compare odor molecules with chemosensory molecule of odor by using different machine learning algorithms. It has make classification, pattern recognition, clustering, regression, and many more as per the research idea. While comparing the molecules, most of the odor molecules are in complex manner and sensory receptor are typically used to complete the communication with data storage of molecule bonding proteins.

TABLE: 1. EXAMPLE OF DIFFERENT ODOR MOLECULES, SHAPE AND CHEMICAL BONDING STRUCTURE.

\begin{tabular}{|c|c|c|c|c|}
\hline Smell & $\begin{array}{l}\text { Molecule } \\
\text { Name }\end{array}$ & $\begin{array}{l}\text { Chemical } \\
\text { Formula }\end{array}$ & Shape & $\begin{array}{c}\text { Chemical } \\
\text { Bonding } \\
\text { Structure }\end{array}$ \\
\hline Fruity & Ethyloctanoate & $\begin{array}{c}\mathrm{C} 10 \mathrm{H} 20 \mathrm{O} \\
2\end{array}$ & & \\
\hline Minty & p-anisaldehyde & $\mathrm{C} 8 \mathrm{H} 8 \mathrm{O} 2$ & & \\
\hline Minty & beta-cyclocitral & $\mathrm{C} 10 \mathrm{H} 13 \mathrm{O}$ & & \\
\hline $\begin{array}{l}\text { Nutty, } \\
\text { Medicinal }\end{array}$ & 4-heptanolide & $\mathrm{C} 7 \mathrm{H} 12 \mathrm{O} 2$ & & \\
\hline $\begin{array}{l}\text { Nutty, } \\
\text { Medicinal }\end{array}$ & $\begin{array}{l}\text { 2,6-dimethyl } \\
\text { pyrazine }\end{array}$ & C6H8N2 & & \\
\hline $\begin{array}{c}\text { fruity scent a } \\
\mathrm{s} \text { nail polish } \\
\text { remover }\end{array}$ & Acetone & $\mathrm{C} 3 \mathrm{H} 6 \mathrm{O}$ & & \\
\hline
\end{tabular}

Above table 1 shows the example of different odor chemical bonding structure. A chemical formula is formulated from different scientist and it is validated by the chemical compound standards.

\section{RECEPTOR CODE FOR ODORS}

Mammalian olfactory system uses different combination of coding scheme to identify and discriminate the encoded odors. Each odor receptor may serve unique chemical structure of receptor codes for many odorant but different odorant are encoded by different combination of odor receiptants. The data presented in the brain also suggest the explanations for several mixing of odors while inhale a gas in the olfactory perception. The basic structure of olfactory sensory system and olfactory receptors used to detect a smell similarly used in animal and human, such system work like a nose called as electronic nose $[8,9,11]$.

The feature of olfactory perception may change dramatically effect by a small changes occurred in a molecule structure. For example acid and alcohols have the same carbon molecule chain in a single functional group but 
having a small differ in it. Therefore the quality of odor depends on the structure of molecule. It is interestingly a single odor is often perceived as a several different odor qualities. For example orange and rose are having the molecule contents like, heptanoic acid and octanol respectively[11].

\section{A. Type of sensor}

PCA: principal component analysis (PCA) is used in the direction of the various cluster algorithms. Clustering algorithm used to revise the honesty of ensuing from various feature extraction techniques. The techniques used to provide visual representation of multidimensional data as odor cluster. The self organizing map (SOM) is used to organize a cluster for the same odor to identify the feature of odor. [3, 7, 12]

VOC: volatile organic compound is a mixture of gases interacts with olfactory epithelium with the intention of stimulate the mammalian brains of smell. When the VOC interacts with surface, a steady state circumstance is reached in a few seconds to few minutes, it is depending on the material and sensor technique $[4,5,9]$.

MOX: metal oxide semiconductor were collect the mixture of data with different sensitivity. MOX sensor response to collect mixed odor sample and generate the wave form corresponding, toward the different ratio of combination of odors. Machine learning algorithm is applied to predict the good without an exceptional apparatus but it require several pre defined measurable compound of odors [11].

\section{B. Algorithms}

SVM: SVM is used to anticipate the waveform of the odor mixture. The terminology of SVM is slightly confusing because it used to referred classification as well as regression (both) algorithms. So researchers may clarify to distinguish between SVC for classification and SVR for regression algorithms [11, 14].

$\mathrm{K}$ NN: KNN is a classification algorithm used to make different classification of odors. It works in a real time scenario and there were no need to retrain the model when new odor are added in the existing databases. This is the beauty of KNN organism. The basic thought of KNN come close to compare the matrix dimensional odor samples . unlabeled odor were stored in a databases with labeled training samples. As per the majority of vote $\mathrm{K}$ closest training sample used, which is measured by the Euclidean distance $[12,13]$.

\section{CLASSIFIER USED BY DIFFERENT RESEARCHERS}

Number of researchers was working on different classifier of Machine-learned odor recognition from physico-chemical properties of volatile molecules algorithms. They were used number of sensors array to predict the molecule of odor. The sensors array may be vary from thought level process. More sensors could be considered for getting better result of odor identification and it will give the good accuracy.

TABLE 2: CLASSIFIER USED BY RESEARCHERS

\begin{tabular}{|c|c|c|c|c|c|c|c|}
\hline $\begin{array}{l}\text { Aut } \\
\text { hor }\end{array}$ & $\begin{array}{l}\text { Classi } \\
\text { fier }\end{array}$ & $\begin{array}{l}\text { Sensor } \\
\text { S }\end{array}$ & $\begin{array}{l}\text { Algori } \\
\text { thm }\end{array}$ & $\begin{array}{l}\text { Olfa } \\
\text { ction }\end{array}$ & $\begin{array}{l}\text { Tech } \\
\text { nique } \\
\text { s } \\
\end{array}$ & $\begin{array}{l}\text { No of } \\
\text { senso } \\
\mathbf{r} \\
\end{array}$ & $\begin{array}{l}\text { Applic } \\
\text { ation }\end{array}$ \\
\hline 4 & $\begin{array}{l}\text { Patter } \\
n \\
\text { recogn } \\
\text { ition }\end{array}$ & $\begin{array}{l}\text { quartz } \\
\text { microb } \\
\text { alance } \\
\text { (QMB) }\end{array}$ & $\begin{array}{l}\text { Nural } \\
\text { networ } \\
\mathrm{k}\end{array}$ & NR & $\begin{array}{l}\text { featur } \\
\text { e } \\
\text { extrac } \\
\text { tion } \\
\text { techni } \\
\text { ques }\end{array}$ & 16 & $\begin{array}{l}\text { medical } \\
\text { applicat } \\
\text { ion }\end{array}$ \\
\hline 17 & $\begin{array}{l}\text { Patter } \\
\mathrm{n} \\
\text { Recog } \\
\text { nition, } \\
\text { ANN }\end{array}$ & $\begin{array}{l}\text { MOX } \\
\text { Sensor }\end{array}$ & $\begin{array}{l}\text { Naviga } \\
\text { tion } \\
\text { algorit } \\
\text { hm }\end{array}$ & $\begin{array}{l}\text { Oxy } \\
\text { gen, } \\
\text { toxic } \\
\text { gas, } \\
\text { expl } \\
\text { osive } \\
\text { gas } \\
\end{array}$ & $\begin{array}{l}\text { GSM, } \\
\text { IoT, } \\
\text { WoT }\end{array}$ & 4 & $\begin{array}{l}\text { Worker } \\
\text { s, } \\
\text { Health, } \\
\text { gas } \\
\text { station }\end{array}$ \\
\hline 18 & $\begin{array}{l}\text { deep } \\
\text { learni } \\
\text { ng } \\
\text { algorit } \\
\text { hms }\end{array}$ & $\begin{array}{l}\text { Quartz } \\
\text { Crystal } \\
\text { Microb } \\
\text { alances }\end{array}$ & $\begin{array}{l}\text { automa } \\
\text { tic } \\
\text { learnin } \\
\mathrm{g} \\
\text { algorit } \\
\text { hms }\end{array}$ & $\begin{array}{l}\text { hexa } \\
\text { nol, } \\
\text { butyl } \\
\text { aceta } \\
\text { te, } 2- \\
\text { hexa } \\
\text { none } \\
\text {, and } \\
\text { hexa } \\
\text { noic } \\
\text { acid }\end{array}$ & $\begin{array}{l}\text { dip } \\
\text { coatin } \\
\text { g } \\
\text { techni } \\
\text { que }\end{array}$ & $\begin{array}{l}28=2 \\
3+5 \\
23 \\
\text { room } \\
\text { tempe } \\
\text { rature } \\
\text { ionic } \\
\text { liquid } \\
\text { s } \\
\text { (RTI } \\
\text { Ls) }\end{array}$ & $\begin{array}{l}\text { atmosp } \\
\text { heric } \\
\text { pollutio } \\
\mathrm{n} \text {, food } \\
\text { industr } \\
\mathrm{y}, \text { for } \\
\text { health } \\
\text { diagnos } \\
\text { is, and } \\
\text { odor } \\
\text { reprodu } \\
\text { ction }\end{array}$ \\
\hline 19 & $\begin{array}{l}\text { featur } \\
\text { e } \\
\text { selecti } \\
\text { on, } \\
\text { patter } \\
\text { n } \\
\text { recogn } \\
\text { ition }\end{array}$ & $\begin{array}{l}\text { MQ-3, } \\
\text { MQ-4, } \\
\text { MQ-6, }\end{array}$ & NR & $\begin{array}{l}\text { benzi } \\
\text { ne, } \\
\text { natur } \\
\text { al } \\
\text { gas, } \\
\text { LPG, } \\
\text { iso- } \\
\text { buta } \\
\text { ne, } \\
\text { and } \\
\text { prop } \\
\text { ane }\end{array}$ & $\begin{array}{l}\text { analyt } \\
\text { ical } \\
\text { techni } \\
\text { ques, } \\
\text { featur } \\
\text { e } \\
\text { extrac } \\
\text { tion } \\
\text { as } \\
\text { well } \\
\text { as } \\
\text { data } \\
\text { proces } \\
\text { sing }\end{array}$ & 6 & $\begin{array}{l}\text { gas- } \\
\text { phase } \\
\text { detectio } \\
\text { n }\end{array}$ \\
\hline 20 & $\begin{array}{l}\text { Suppo } \\
\text { rt } \\
\text { Vector } \\
\text { Machi } \\
\text { ne } \\
\text { (SVM } \\
\text { ), } \\
\text { Back } \\
\text { Propa } \\
\text { gation } \\
\text { Neural } \\
\text { Netwo } \\
\text { rk } \\
\text { (BPN } \\
\text { N) }\end{array}$ & NR & $\begin{array}{l}\text { Expect } \\
\text { ation- } \\
\text { Maxim } \\
\text { ization } \\
\text { (EM) } \\
\text { algorit } \\
\text { hm }\end{array}$ & NR & $\begin{array}{l}\text { Patter } \\
\mathrm{n} \\
\text { recog } \\
\text { nition }\end{array}$ & 16 & $\begin{array}{l}\text { Medica } \\
\text { 1, food, } \\
\text { environ } \\
\text { mental, } \\
\text { explosi } \\
\text { ve } \\
\text { detectio } \\
\text { n }\end{array}$ \\
\hline
\end{tabular}




\begin{tabular}{|c|c|c|c|c|c|c|c|}
\hline $\begin{array}{l}\text { Aut } \\
\text { hor }\end{array}$ & $\begin{array}{l}\text { Classi } \\
\text { fier }\end{array}$ & Sensors & $\begin{array}{l}\text { Algor } \\
\text { ithm }\end{array}$ & $\begin{array}{l}\text { Olfacti } \\
\text { on }\end{array}$ & $\begin{array}{l}\text { Techn } \\
\text { iques }\end{array}$ & $\begin{array}{l}\text { No } \\
\text { of } \\
\text { sen } \\
\text { sor }\end{array}$ & $\begin{array}{l}\text { Applic } \\
\text { ation }\end{array}$ \\
\hline 21 & $\begin{array}{l}\text { neural } \\
\text { netwo } \\
\text { rk }\end{array}$ & $\begin{array}{l}\text { TGS260 } \\
\text { 2, } \\
\text { TGS261 } \\
\text { 1, } \\
\text { TGS262 } \\
0 \text {, and } \\
\text { TGS880 } \\
\text { from } \\
\text { Figaro, } \\
\text { Inc. } \\
\text { (Japan); }\end{array}$ & $\begin{array}{l}\text { Bioni } \\
\text { c } \\
\text { olfact } \\
\text { ory } \\
\text { cortex }\end{array}$ & NR & NR & 35 & NR \\
\hline 22 & $\begin{array}{l}\text { SVM, } \\
\text { PCA }\end{array}$ & $\begin{array}{l}\text { TGS260 } \\
0, \\
\text { TGS260 } \\
2, \\
\text { TGS261 } \\
0, \text { and } \\
\text { TGS262 } \\
0\end{array}$ & $\begin{array}{l}\text { CNN } \\
\text { featur } \\
\text { e } \\
\text { extrac } \\
\text { tion }\end{array}$ & $\begin{array}{l}\text { acetalde } \\
\text { hyde- } \\
\text { toluene } \\
\text { mixture } \\
\text { s }\end{array}$ & $\begin{array}{l}\text { feature } \\
\text { extract } \\
\text { ion }\end{array}$ & 16 & $\begin{array}{l}\text { Bio- } \\
\text { inspire } \\
\mathrm{d} \\
\text { applica } \\
\text { tions }\end{array}$ \\
\hline 23 & $\begin{array}{l}\text { Back- } \\
\text { propa } \\
\text { gation } \\
\text { neural } \\
\text { netwo } \\
\text { rk } \\
\text { (BPN } \\
\mathrm{N} \text { ), } \\
\text { suppor } \\
\mathrm{t} \\
\text { vector } \\
\text { regres } \\
\text { sion } \\
\text { (SVR) } \\
\text {, and } \\
\text { partial } \\
\text { least } \\
\text { square } \\
\text { regres } \\
\text { sion } \\
\text { (PLSR } \\
\text { ). }\end{array}$ & $\begin{array}{l}\text { Metal } \\
\text { oxide } \\
\text { semicon } \\
\text { ductor } \\
\text { (MOS) }\end{array}$ & $\begin{array}{l}\text { BPN } \\
\text { N, } \\
\text { SVM, } \\
\text { PLSR }\end{array}$ & $\begin{array}{l}\text { biologic } \\
\text { al } \\
\text { olfactio } \\
\mathrm{n}\end{array}$ & $\begin{array}{l}\text { statisti } \\
\text { cal } \\
\text { techni } \\
\text { ques }\end{array}$ & 10 & $\begin{array}{l}\text { foods, } \\
\text { medici } \\
\text { nes, } \\
\text { bevera } \\
\text { ges, } \\
\text { and } \\
\text { the } \\
\text { enviro } \\
\text { nment }\end{array}$ \\
\hline
\end{tabular}

Note: NR-Not recorded

Haddad, Rafi, et al. discussed the Lorentzian method, commonly used in e-nose application. It is lengthy process need to be fixed. In the case of large number of odorant, similar to Lorentzian method used name as feature extraction. It is easy to apply for all the odorant signals, which extract four parameters combined with 16 sensors of the e-nose [4]. Experiment was done by Haddad, Rafi, et al. used eight metal-oxide (MOX) sensors and eight quartz microbalance (QMB) sensors which used in medical applications, workers, health, gas stations [4].

Abdullah, A. H., et al. discussed web based mobile olfaction system for hazardous gas monitoring. Workers may work in any area that contains hazardous gas leakage. Abdullah, A. H., et al. develop a noses prototype, integrate with mobile robot. Prototype contains web based GSM communication module, to monitor the hazardous gas by using ANN model. Four sensors were used to detect the odor through IoT framework [17].

Aleixandre, Manuel, and Takamichi Nakamoto used 28 quartz crystal microbalance sensors, out of 23 sensors were used in different room temperature ionic liquids (RTILs) and 5 QCM sensors in gas chromatography. Possible problem studied is the temperature and humidity influence. Author analysis frequency data for better classification and further improves the discrimination power [18].

Liu, Huixiang, et al. propose maximum independence of the concentration features (MICF) using Iterative Fisher Linear Discriminant (IFLD) achieved an accuracy of $76.17 \%$. Back propagation neural network classifier considers pattern recognition using 16 sensors. The application is derived in medical, food, and explosive area [20].

Yalçın, Müştak E., et al. discuss the feature extraction of CNN model considering biological signal/image processing. SVM, PCA classifier were used to detect mixture of odor using array of 16 sensors. Yalçın, Müştak E., et al. consider two sets A and B, Set A responses for a pure acetaldehyde, $\mathbf{b}$ pure toluene, and c acetaldehyde-toluene mixtures. Set B contains five type of odors namely, Acetaldehyde, acetone, butane, ethylene, and ethane. The CNN model tested using set A with PCA and SVM classifier for bio-inspired application [22].

Zhu, Longtu, et al. suggest soil organic regression model namely back-propagation neural network (BPNN), support vector regression (SVR) and partial least squares regression (PLSR). Zhu, Longtu, et al. suggest to detect artificial olfaction by predicting soil organic matter content. While predicting various factors considered including temperature, soil moisture, soil sealing time, within order to optimize soil contents [23].

TABLE 3 SHOWS THE CLASSIFIER VS NUMBER OF SENSORS

\begin{tabular}{|l|c|}
\hline \multicolumn{1}{|c|}{ Classifier } & No of Sensor \\
\hline Pattern Recognition & 20 \\
\hline deep learning algorithm & 28 \\
\hline feature selection & 6 \\
\hline support vector machine & 16 \\
\hline neural network & 35 \\
\hline back propagation model & 10 \\
\hline
\end{tabular}




\section{Classifier Vs no of sensor}

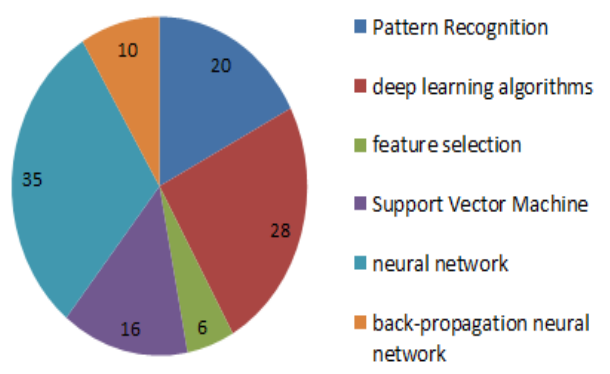

Fig. 6: classifier Vs no of sensors

Fig. 6 presents the array of number of sensors. Most of the work carried out with neural network by consideration of Matlab, followed by deep learning, pattern recognition, and support vector machine by machine learning algorithms.

\section{CONCLUSION}

In this article a short description of digital representation of odor was given. Olfaction terminology is new in the era to describe the odor analysis, how those odor sensors were used to predict the molecule. To analyze the specific odor human/animal can search the specific pattern and match that pattern using their thought level process. The same techniques used to identify odor in the field of computer science and engineering with the help of portable device called as electronic nose. That electronic nose will be predict the pattern by using classification and regression techniques applied in machine learning by using different types of sensor.

\section{REFERENCES}

[1] Axel, Richard. "The Molecular Logic Of Smell." Scientific American, vol. 16, no. 3s, Sept. 2006, pp. 68-75. DOI.org (Crossref), doi:10.1038/scientificamerican0906-68sp.

[2] Grabe, Veit, and Silke Sachse. "Fundamental Principles of the Olfactory Code." Biosystems, vol. 164, Feb. 2018, pp. 94-101. DOI.org (Crossref), doi:10.1016/j.biosystems.2017.10.010.

[3] Gutierrez-Osuna, R. "Pattern Analysis for Machine Olfaction: A Review.” IEEE Sensors Journal, vol. 2, no. 3, June 2002, pp. 189202. DOI.org (Crossref), doi:10.1109/JSEN.2002.800688.

[4] Haddad, Rafi, et al. "Predicting the Receptive Range of Olfactory Receptors." PLoS Computational Biology, edited by Edmund John Crampin, vol. 4, no. 2, Feb. 2008, p. e18. DOI.org (Crossref), doi:10.1371/journal.pcbi.0040018.

[5] Hogan, Aneila V. C., et al. "Comparative Growth in the Olfactory System of the Developing Chick with Considerations for Evolutionary Studies." Journal of Anatomy, vol. 237, no. 2, Aug. 2020, pp. 225-40. DOI.org (Crossref), doi:10.1111/joa.13197.

[6] Karami, Hamed, et al. "Qualitative Analysis of Edible Oil Oxidation Using an Olfactory Machine." Journal of Food Measurement and Characterization, June 2020. DOI.org (Crossref), doi:10.1007/s11694020-00506-0.

[7] Kermit, M., and O. Tomic. "Independent Component Analysis Applied on Gas Sensor Array Measurement Data." IEEE Sensors Journal, vol. 3, no. 2, Apr. 2003, pp. 218-28. DOI.org (Crossref), doi:10.1109/JSEN.2002.807488.
[8] Malnic, B., et al. "Combinatorial Receptor Codes for Odors." Seibutsu Butsuri, vol. 39, no. supplement, 1999, p. S54. DOI.org (Crossref), doi:10.2142/biophys.39.S54_2.

[9] Nagle, H. T., et al. "The How and Why of Electronic Noses." IEEE Spectrum, vol. 35, no. 9, Sept. 1998, pp. 22-31. DOI.org (Crossref), doi: $10.1109 / 6.715180$.

[10] Pearce, T. C., editor. Handbook of Machine Olfaction: Electronic Nose Technology. Wiley-VCH, 2003.

[11] Phaisangittisagul, Ekachai, and H. Troy Nagle. "Predicting Odor Mixture's Responses on Machine Olfaction Sensors." Sensors and Actuators B: Chemical, vol. 155, no. 2, July 2011, pp. 473-82. DOI.org (Crossref), doi:10.1016/j.snb.2010.12.049.

[12] Roppel, Thaddeus, and Denise M. Wilson. "Biologically-Inspired Pattern Recognition for Odor Detection.” Pattern Recognition Letters, vol. 21, no. 3, Mar. 2000, pp. 213-19. DOI.org (Crossref), doi:10.1016/S0167-8655(99)00150-6.

[13] Salminen, Katri, et al. "Olfactory Display Prototype for Presenting and Sensing Authentic and Synthetic Odors." Proceedings of the 2018 on International Conference on Multimodal Interaction - ICMI '18, ACM Press, 2018, pp. 73-77. DOI.org (Crossref), doi:10.1145/3242969.3242999.

[14] Tromelin, Anne, et al. "Exploring the Characteristics of an AromaBlending Mixture by Investigating the Network of Shared Odors and the Molecular Features of Their Related Odorants." Molecules, vol. 25, no. 13, July 2020, p. 3032. DOI.org (Crossref), doi:10.3390/molecules 25133032

[15] Ivan Mehta [https://thenextweb.com/artificialintelligence/2019/10/24/google-is-training-an-ai-to-predict-amolecules-smell/]

[16] Alexander B Wiltschko, Senior Research Scientist, Google Research [https://ai.googleblog.com/2019/10/learning-to-smell-using-deeplearning.html]

[17] Abdullah, A. H., et al. "Development of Web-Based Mobile Olfaction System for Confined Space Hazardous as Monitoring." IOP Conference Series: Materials Science and Engineering, vol. 705, Dec. 2019 , p. 012042. DOI.org (Crossref), doi:10.1088/1757899X/705/1/012042.

[18] Aleixandre, Manuel, and Takamichi Nakamoto. "Study of Room Temperature Ionic Liquids as Gas Sensing Materials in Quartz Crystal Microbalances." Sensors, vol. 20, no. 14, July 2020, p. 4026. DOI.org (Crossref), doi:10.3390/s20144026.

[19] Borowik, Piotr, et al. "Odor Detection Using an E-Nose With a Reduced Sensor Array." Sensors, vol. 20, no. 12, June 2020, p. 3542. DOI.org (Crossref), doi:10.3390/s20123542.

[20] Liu, Huixiang, et al. "A Suppression Method of Concentration Background Noise by Transductive Transfer Learning for a Metal Oxide Semiconductor-Based Electronic Nose." Sensors, vol. 20, no. 7, Mar. 2020, p. 1913. DOI.org (Crossref), doi:10.3390/s20071913.

[21] Liu, Ying-Jie, et al. "Electronic Nose Using a Bio-Inspired Neural Network Modeled on Mammalian Olfactory System for Chinese Liquor Classification." Review of Scientific Instruments, vol. 90, no. 2, Feb. 2019, p. 025001. DOI.org (Crossref), doi:10.1063/1.5064540.

[22] Yalçın, Müştak E., et al. "Artificial Olfaction System." Reconfigurable Cellular Neural Networks and Their Applications, by Müştak E. Yalçın et al., Springer International Publishing, 2020, pp. 23-50. DOI.org (Crossref), doi:10.1007/978-3-030-17840-6_3.

[23] Zhu, Longtu, et al. "A Novel Method for Soil Organic Matter Determination by Using an Artificial Olfactory System.” Sensors, vol. 19, no. 15, Aug. 2019, p. 3417. DOI.org (Crossref), doi:10.3390/s19153417. 